This work is licensed under a Creative Commons Attribution 4.0 International License.

Ovaj rad dostupan je za upotrebu pod licencom Creative Commons Imenovanje 4.0 međunarodna.

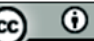

Emina BERBIĆ KOLAR

Fakultet za odgojne i obrazovne znanosti

Sveučilište J. J. Strossmayera u Osijeku

Ulica cara Adrijana 10

HR - 31000 Osijek

eberbic@foozos.hr

Josip JAGODAR

Osnovna škola „Dr. Stjepan Ilijašević“

Frankopanska 97

HR - 35250 Oriovac

jjagodar91@gmail.com
UDK 398.8(497.5 Slavonski Kobaš)

DOI: https://doi.org/10.29162/ANAFORA.v7i1.6

Pregledni članak

Review Article

Primljeno 27. prosinca 2019.

Received: 27 December 2019

Prihvaćeno 26. svibnja 2020.

Accepted: 26 May 2020

\title{
KOBAŠKA ŠETANA KOLA - PRINOSI PROUČAVANJU SLAVONSKE NEMATERIJALNE KULTURNE BAŠTINE
}

\section{Sažetak}

Radom će se prikazati kulturološki i identitetski značaj šetanih kola posavskoga sela Slavonski Kobaš i to: kola „polako“ i kola „na brzo“ kao dio nematerijalne kulturne baštine i tradicije hrvatskoga naroda. Šetana kola zaštićena su kao nematerijalno kulturno dobro od 2009. godine. Točnije rečeno, zaštićena su drežnička šetana kola, a predmetom ovoga rada bit će kobaška šetana kola koja pripadaju istom geografskom i kulturološkom krugu kao i drežnička. Šetana kola važan su element kulturnoga identiteta šokačke kulture i šokačkoga identiteta. Cilj je rada dati doprinos proučavanju šetanih kola koja su neopravdano zanemarena i u znanstvenim, i u stručnim krugovima, a čiji je značaj i u kulturološkom, i u etnološkom, i u povijesnom, i u lingvističkom, i književnopovijesnom kontekstu izrazito velik te ukazuje na mogućnost proučavanja slojevitosti tekstova šetanih kola kao predložaka za iščitavanje povijesti, usmene književnosti, jezika vremena u kojemu su nastajala, etnologije, identiteta i općenito kulturološkoga poimanja naroda za koji su vezana kao dio kulturne baštine i identiteta jednoga kraja. Rad se temelji na metodama 
terenskoga prikupljanja građe (tekstovi šetanih kola), analiziranja i usustavljivanja prikupljene građe te rada na dostupnoj arhivskoj građi.

Ključne riječi: šetana kola, Slavonski Kobaš, Posavina, usmena književnost, mjesni govor

\section{Uvod}

Slavonski Kobaš mjesto je u brodskoj Posavini u kojem žive pretežno Šokci. U srednjem vijeku postojale su dvije utvrde, a toponim Kopas possessio prvi se puta spominje 1470. godine kao posjed Berislavića. Turci su osvojili Kobaš 1530. godine i u njemu ostali (uz povremene prekide) do 1691. kada je na područje Kobaša došla austrijska vojska i ondje nastanila kordon vojske (usp. Jagodar i Berbić Kolar 2020: 8). Vojna uprava djelovala je do 1872., kada je osnovana Upravna obćina Kobaš kojoj su pripadala sela Kobaš i Novo Selo (Isto: 21). Od 19. stoljeća Kobaš se razvijao kao općina koja se bavila ponajprije poljoprivredom i stočarstvom, a na području općine živjelo je i dosta obrtnika, trgovaca i gostioničara, postojala je parobrodarska postaja, stoga se može zaključiti da je općina Kobaš bila jedna od razvijenih općina na području Kotara Oriovac. Općina Slavonski Kobaš ukinuta je nakon Drugog svjetskog rata, a danas mjesto Slavonski Kobaš pripada općini Oriovac. Društveni i kulturni život na području Kobaša razvija se više od stoljeća, tj. od 1922. godine, ${ }^{1}$ a prije toga su se značajni događaji i osobe iz prošlosti Slavonskog Kobaša opjevavali u usmenim pjesama koje su se izvodile u različitim prilikama te u šetanim kolima. Danas su članovi Kulturno-umjetničkog društva „Matija Gubec“ čuvari bogate kulturne i folklorne baštine Slavonskog Kobaša jer u svojim nastupima na raznim manifestacijama izvode kobaška kola i napjeve koji su u kola i pjesme ušli iz usmene književnosti. U radu će se navesti tekstovi pojedinih pjesama iz kobaških šetanih kola - kola „polako“ i kola „na brzo“. Kazivačica koja je govorila stihove triju pjesama počimalja je KUD-a „Matija Gubec“Valentina Džinić, a ostali tekstovi preuzeti su iz objavljenih knjiga Mihaela Ferića (2016.) te Josipa Jagodara i Emine Berbić Kolar (2020.).

\footnotetext{
${ }^{1}$ Dana 15. siječnja 1922. godine osnovana je Hrvatska seljačka čitaonica, a iste su godine Manda Sekulić i Kata Katanić organizirale zabavu na kojoj su nastupili kobaški tamburaši (Jagodar i Berbić Kolar 2020: 182). Ljudi su bili oduševljeni kad su vidjeli kako tamburaši u narodnoj nošnji pjevaju i sviraju „narodne pjesme“ (2005: 66-67, 237).
} 


\section{Usmena književnosti i pjesme pjevane u kolima}

Neraskidiva je veza između usmene književnosti i šetanih kola koja se izvode u brodskoj Posavini i šire. Solar navodi da se usmena književnost „prenosi (...) i razvija u sredinama koje ne poznaju pismo ili se pismom zbog bilo kakvih razloga ne služe radi prenošenja književnih djela" (Solar 1994: 125). On smatra da je usmena književnost doživjela „procvat“ kada je samo manji dio pučanstva bio pismen i da ona „prethodi pisanoj književnosti (...) zadržava i razvija i u pojedinim sredinama odnosno zajednicama gdje je pismenost rjeđa nego u drugim sredinama (npr. u seoskim sredinama je rjeđa nego u gradskim)“ (Isto). Kekez navodi da je usmena književnost važan čimbenik i da je njezin društveni status „utjecao na opseg i način njezina utoka u pisanu književnost“, ali da je do danas „izgubila onu snagu društvenog opticaja koju je imala dugi niz stoljeća“ (Kekez 1988: 197). Botica donosi proširenu definiciju i usmenu književnost definira kao jezičnu umjetničku tvorevinu nastalu: „usmenim načinom u prošlosti (...). Stara je koliko je star i čovjek koji ju je stoljećima stvarao, čuvao i prenosio naraštajima usmenim prepričavanjem. To je, dakle, književnost koja je dostupna svima, i pismenima i nepismenima, a oblikovana je tako da ju svi razumiju. Tvorac tekstova daroviti je pojedinac iz naroda koji osjeća važnost riječi, što ga čini sposobnim da stvara lako pamtljive strukture, koje se dalje prenose u originalnom ili blago izmijenjenom obliku." (Botica 1995: 9)

Iz njihovih se definicija može zaključiti da se usmena književnost razvija od darovitih pojedinaca koji su djelovali u sredinama ${ }^{2}$ gdje je bilo nepismeno stanovništvo te je ona opstala jer se prenosila s koljena na koljeno. Jakobson i Bogatirjov (1971: 18) naglašavaju značaj jezične zajednice za usmeno pjesništvo: „Postojanje neke folklorne tvorevine kao takve počinje tek onda kada ju je određena zajednica prihvatila, a od te tvorevine postoji samo ono što je zajednica usvojila." Smatraju da je u narodima nastalo i više djela usmene književnosti, ali se ona nisu sačuvala jer ih određena zajednica nije prepoznala i prihvatila, stoga ih zapisivači nisu mogli sačuvati te to nazivaju preventivnom cenzurom zajednice (Isto 18, 20). U nastavku rada prikazuju se pjesme šetanih kola koje su dio usmene, tj. folklorne baštine. Upravo zbog pripadnosti folklornoj baštini, tekstovi šetanih kola, očuvani su od zaborava i sačuvani u izvornom obliku do današnjih dana.

\footnotetext{
${ }^{2}$ Kekez (1988: 197) smatra da je znatan broj stvaralaca bio iz ruralnih područja.
} 
Pjesme iz usmene književnosti opjevale su se i u različitim kolima, što potvrđuje Ilić Oriovčanin (1846: 205-206) navodeći nekoliko pjesama „za upoznati duh narodnih pěsamah, koje se u kolu pěvaju“ te „Osim narodnih pěsamah mogu se i zagonetke na prelih čuti. Junačke se pako narodne pěsme na město pripovědkih pripovědaju“ (Isto: 222). Usmena književnost slušala se na prelima gdje su žene, djevojke i bake čijale perje i prele, a dječaci, momci i djedovi sjedili oko njih i pjevali uz vino i rakiju. Mnogi povijesni događaji opjevani su u zimskim noćima kad seljaci nisu mogli raditi u polju ili u vrtu pa su noći kratili druženjem uz pjesme i igranje kola. Osim na prelima, usmene pjesme pjevale su se u kolima i tijekom ljeta na sijelima. ${ }^{3}$ Ivančan (1963: 97) navodi da u Slavoniji odlazak u kolo znači ,ići u skup ljudi koji se okupljaju na plesnom prostoru, a ne samo ići plesati." Pjesme i poskočice u kolu govore o različitim problemima: o ljubavi, obitelji, religiji, politici i socijalnim zbivanjima, stoga su se ljudi okupljali oko kola i slušali o čemu pjevači pjevaju te su na taj način doznavali različite novosti. U kolima su se mladi upoznavali te se ondje dolazilo do različitih pogleda, šala i razgovora (usp. Ivančan 1963: 97-99). Bošković-Stulli (1971: 38) navodi da „djela usmene književnosti podliježu utjecajima vremena i okoline“, stoga mijenjaju pojedina obilježja i kontekst, ali im se nikada ne mijenja osnovna struktura. U hrvatsku terminologiju usmene književnosti balada ulazi u 19. stoljeću raspravama Franje Markovića, zajedno s pojmom bugarštice i romance. Bugarštice su posebne usmene pjesme koje tematiziraju ljudska unutarnja stanja i obično imaju žalostan završetak. Pisane su najčešće petnaestercem ili šesnaestercem, a nakon dugog stiha slijedio je pripjev koji je najčešće u šestercu (Kekez i Pandžić 1996: 8-9). Simona Delić smatra da je u Hrvatskoj prisutna „duga tradicija bilježenja kraćih usmenih propovjednih pjesama“ i da su se balada i bugarštice na području današnje Hrvatske pojavile već u 15. stoljeću, ali je balada do prve polovice 20. stojeća bila „zanemaren žanr“ (2001: 5-6, 9). Nadalje, navodi da su balade pjesme koje se pjevaju „za vrijeme preskakanja vatre na Ivanje“ te uz kolo (Isto: 10).

\footnotetext{
${ }^{3}$ Kekez i Pandžić (1996: 7) navode da su se usmene pjesme prenosile najčešće pjevanjem na „skupovima ljudi, tijekom ili nakon obavljanja nekoga posla: na okupljanjima uz pojedine blagdane i proslave zaštitnika župa, na sijelima, prelima, vezenju, komušanju kukuruza, listanju duhana, čehanju perja, striženju ovaca, pripremi voća za sušenje, svatovima, pogrebima, uspavljivanju djece i dr.“
}

${ }^{4}$ Više u: Bošković-Stulli (2005: 5-58). 


\section{2. Šetana kola kao primjer nematerijalne kulturne baštine}

Šetana su kola specifična za područje cijele Slavonije. Ferić (2016: 117) navodi: „U slavonskom folklornom plesu najstariji su i najbrojniji plesovi koji se izvode isključivo uz pjevanje, šetani i ubrzani korak“. O šetanim kolima pronalazimo podatke u knjizi „Hrvatski običaji i druge tradicije“ u kojoj se definiraju područja u kojima se plešu šetana kola i u kojem razdoblju se plešu: „Vođenje kola, tzv. pjevanih ili šetanih kola najčešće u uskrsno doba, u običajima proljetnoga ciklusa i za Ivanje oko krijesa te u svadbi oko stola, table, uz pjevanje baladnih stihova, kao stariji tradicijski sloj plesne kulture, do kraja 19. stoljeća još je bilo dobro poznato u Hrvatskom zagorju, Podravini i Međimurju. Ta su kola imala ritualnu funkciju, a najčešće su povezana s kultom plodnosti i stalnog obnavljanja života“ (Zebec u: Vitez i sur. 2016: 230).

Šetana su kola spoj nekoliko kulturoloških elemenata, u njima se sjedinjuju glazba, ples i usmena književnost. U njima se ogleda bogatstvo šokačke kulture i šokačkih tradicijskih vrijednosti. Tekstovi šetanih kola služili su najčešće za zabavu i rasterećenje, u šetanim se kolima poučavalo o svim elementima svakodnevnoga života, od povijest (ratovi protiv Turaka, Prvi svjetski rat, Drugi svjetski rat), geografije (bliža i dalja sela koja su okruživala selo, ali i prekosavske krajeve Bosne i Hercegovine), higijene, domaćinstva (kako biti dobra mlada), usmene predaje pa sve do nekih humorističnih situacija kojima je svrha bila rasteretiti i nasmijati. Veliki zaljubljenik u posavsku tradicijsku kulturu je glazbeni pedagog i muzikolog Mihael Ferićs koji je dobrim dijelom i zaslužan za zapisani korpus šetanih kola koja su nam poslužila kao temelj u analizi i interpretaciji. Ferić (2016: 117) spominje da je svim slavonskim napjevima zajedničko da su oni kratki, lako pamtljivi, da imaju malen tonski opseg i poduže epske ili lirske stihove te da se pjevaju u dvoglasju i većinom u dvije skupine. Šetana kola Ferić naziva i pjevanima ili „kolo na jalovo“ (Isto: 118).

Šetano je kolo zaštićeno kao nematerijalno kulturno dobro Republike Hrvatske 2009. godine. Zaštićeno je šetano kolo Drežnika iz općine Rešetari kod Nove Gradiške. Elaborat zaštite kao i sve druge popratne aktivnosti odradila je

\footnotetext{
${ }^{5}$ Mihael Ferić rođen je 1939. godine u Slavonskom Kobašu. Poznati je glazbeni pedagog, promicatelj tamburaške glazbe, melograf i dirigent te autor nekoliko knjiga tamburaške glazbe i niza stručnih članaka objavljenih u nekoliko publikacija. Zaslužan je za uvrštavanje bećarca na UNESCO-ovu listu nematerijalne kulturne baštine 2011. godine (Ferić 1996: zadnje korice; Berbić Kolar i Jagodar).
} 
etnomuzikologija Miroslava Hadžihusejinović. Ministarstvo kulture Republike Hrvatske definiralo je pojam nematerijalne kulturne baštine:

„Nematerijalna kulturna baština definirana je člankom 2. UNESCO-ove Konvencije o zaštiti nematerijalne kulturne baštine (NN 5/05) i člankom 9. Zakona o zaštiti i očuvanju kulturnih dobara u okviru kojega se za potrebe upisa u Registar kulturnih dobara Republike Hrvatske određuju tri osnovne kategorije:

- jezik, dijalekti, govori i toponimika, te usmena književnost svih vrsta,

- folklorno stvaralaštvo u području glazbe, plesa, predaje, igara, obreda, običaja, kao i druge tradicionalne pučke vrednote,

- tradicijska umijeća i obrti“满

Kao što je vidljivo iz prethodnoga navoda, šetana su kola dio nematerijalne kulturne baštine te se njihov značaj i način realizacije (izvedbe) preklapa kroz prva dva navedena područja povezujući usmenu književnost, jezik, dijalekte, govor s folklornim stvaralaštvom u području glazbe i plesa. Uz šetana kola, kao nematerijalno kulturno dobro, veže se pojam kulturnoga identiteta koji se, kako navodi Orlović, definira kao: „(...) jedinstvenost i autentičnost jedne kulture, pripadnost pojedinca ili društvene skupine toj kulturi, određenje jedne zajednice po njezinim vlastitim kulturnim osobitostima i vrijednostima. Svaka generacija ima svoj doživljaj prenošenja iskustva, što potvrđuje činjenicu da je kulturni identitet promjenjiv. Te promjene ovise o događajima koji ugrožavaju stabilnost kulturnih elemenata zajedničkih sjećanja i predstave o kolektivnoj sudbini, a mogu poremetiti temeljne vrijednosti koje su temelj kulturne različitosti čine nas drugačijima od „drugih“. Koji će kulturni elementi obilježiti identitet grupe ovisi o brojnim čimbenicima, kao što su ekonomski, politički, društveni i psihološki faktori određenoga vremena." (Ilić 2018: 6 prema Orlić 2013.)

Šetana su kola izvor proučavanja i poučavanja ne samo baštine u vrlo širokom kontekstu značenja, nego i za proučavanje povijesti i usmene književnosti te mjesnoga govora na kojemu je šetano kolo zapisano, odnosno ispjevano, izgovoreno. Tekstovi se šetanih kola svrstavaju u balade. Za baladu Solar kaže da je nastala od provansalskog balar što znači plesati te je u mnogočemu slična romanci i ona pripada prvom tipu balada koje su nastale kao plesne pjesme u Provansi u 13. stoljeću. Također navodi da postoji i drugi tip balade tzv. sjevern-

${ }^{6}$ Preuzeto s url: https://www.min-kulture.hr/default.aspx?id=21765, 30. 3. 2020. 
jačka balada koja je nastala u Škotskoj. Balada pjeva o stradanjima i nesrećama polaganijim ritmom koji nosi tužnu intonaciju (Solar 1994: 196). Stipe Botica usmene lirske pjesme dijeli u dvije opće kategorije u kojima je čovjek u središtu. U prvu kategoriju, prema Botici, pripadaju one pjesme koje opisuju čovjekov odnos prema svijetu oko sebe. Sljedeća kategorija prikazuje pjesme u kojima je riječ o ljudskome životu. Prema tim dvjema kategorijama može se zaključiti kako su najčešći motivi oni o majci, bratu, junaku, o prirodnim ljepotama i dr. Što se tiče stiha, on je u obje kategorije promjenjiv, odnosno može se reći da varira od osmerca do dvanaesterca (Botica 1995: 17).

\section{Narodni pjesnici i zapisivači usmenih pjesama iz Slavonskog Kobaša}

Mnogi su slavonski pjesnici zaslužni za očuvanje usmenih slavonskih pjesama, osobito zbog toga što su veći dio Slavonije u 16. stoljeću zauzeli Turci i otišli tek potkraj 18. stoljeća. Od slavonskih pjesnika treba istaknuti Matiju Antuna Relkovića, Vida Došena, Antuna Ivanošića, Matiju Petra Katančića i druge (usp. Hadžihusejnović-Valašek 2002: 202-205) jer su oni opisali svakodnevni život u razdoblju u kojem su živjeli i koji se prenosio s koljena na koljeno. Zapisivači rukopisnih pjesmarica bili su plemići, svećenstvo i pismeni građani, prepisivali su pjesme iz jedne u drugu zbirku te je nastajala nova poezija jer su zapisivači unosili vlastite stihove i stihove anonimnih autora (Bošković-Stulli 1978: 233).

Ilirac Luka Ilić Oriovčanin jedan je od zapisivača usmenih pjesama i običaja koji je u svojim knjigama zapisao i nekoliko pjesama iz današnjeg Slavonskog Kobaša. ${ }^{7}$ Osim njega, za Slavonski Kobaš značajni su Kobašani i Kobašanke koji su zapisivali usmene pjesme koje su čuli u selu. Zapisivači su bili Janja Krištofić (1868. - 1961.), Tera Blažić (1895. - ?), ${ }^{8}$ Jula Živković (1907. - 1983.), Terezija (Reza) Sekulić (1924. - 1988.), a najpoznatiji je među njima glazbeni pedagog Mihael Ferić te etnolog i povjesničar Zvonimir Toldi (1944.). Zapisivači su zapisivali pjesme koje su čuli u šetanim i drugim kolima, na prelima, sijelima, na različitim manifestacijama u kojima su nastupali članovi Kultur-

\footnotetext{
${ }^{7}$ U knjizi Narodni slavonski običaji zapisao je i dvije pjesme iz Kobaša (1946: 37-40, 49-50), a u knjizi Lovorike gradiškoga narodnoga graničarskoga puka br. 8. na više mjesta spominje Kobaš i poznate kobaške junake koji su se borili protiv Turaka (1874: 11, 48, 51-52, 70-73, 75, 78, 85-87, 92-97, 102, 104-115, 165-166). Više u: Jagodar (2019: 59-74).

${ }^{8}$ Kata Sekulić navodi da je Tera Blažić sakupljala i zapisavala pjesme, ali ne zna kod koga bi mogla biti njezina ostavština.
} 
no-umjetničkog društva „Matija Gubec “9 iz Slavonskog Kobaša, a dio su i sami smislili po uzoru na pjevane pjesme. Janja Krištofić (djevojački Mitrović) bila je žena postolara Stjepana Krištofića i zapisivala je pjesme. ${ }^{10}$ Žene obrtnika u selu su nazivali „majstorice“ $\mathrm{i}$ one su uživale određeni ugled jer su majstori bili cijenjeni. Mnogi Kobašani potvrdili su da je Janja zapisivala pjesme koje su se pjevale u kolima u Kobašu krajem 19. i početkom 20. stoljeća, a dosad je objavljena samo jedna njezina autorska pjesma „Polnoćka“ (Berbić Kolar i Jagodar 2020: 413). Jula Živković napisala je pjesmaricu od 76 pjesama, koju su objavili Jagodar i Berbić Kolar (2020: 372-390). Pjesme iz njezine pjesmarice izvode članovi KUD-a „Matija Gubec“ iz Slavonskog Kobaša u raznim prigodama, a najpoznatije su izvedbe pjesme ispjevane u šetanim kolima. Terezija Sekulić zapisivala je većinom pjesme vjerskog sadržaja, a dosad je objavljeno 17 pjesama koje su posvećene Majci Božjoj Kloštarskoj, Gospi Lurdskoj te pjesme vezane uz svetu krunicu i otajstva (Isto: 400-412). Mihael Ferić zapisao je i objavio 14 pjesama koje se plešu i pjevaju u Slavonskom Kobašu (Ferić 1996: 158-175). On je zapisao pjesme s notnim zapisima po pjevanju članova KUD-a „Matija Gubec“ od 1962. do 1995. godine. Među njima se nalazi i nekoliko pjesama koje se pjevaju u šetanim kolima i koje će biti analizirane u nastavku rada. Zvonimir Toldi značajan je po tome što je objavio nekoliko bećaraca iz Slavonskog Kobaša u svojim knjigama (Toldi 1985: 54, 57; 1994: 92). U posljednje se vrijeme Josip Jagodar (1991.) bavi proučavanjem prošlosti Kobaša te zapisivanjem kobaških običaja i folklora vezanih uz Slavonski Kobaš. Zapisivači usmenih pjesama znali su da samo zapisivanjem mogu sačuvati identitet, kulturnu i folklornu baštinu Slavonskog Kobaša. U nastavku rada obradit će se izbor iz pjesama koje su se pjevale u kobaškim šetanim kolima: kolu „polako“ i kolu „na brzo“.

\section{Kola „polako“}

Ponajprije treba definirati kretanje u kolu. Ivančan (1964: 24) navodi da je pomicanje u kolu „vrlo blago“ i „svladava se neznatan prostor“. Upravo taj opis može se koristiti i za definiranje kola „polako“ koje se pleše u Slavonskom Kobašu više od jednog stoljeća koje su Kobašanke i Kobašani njegovali svake nedjelje i blagdanom te u svatovima, za vrijeme poklada i drugim prigodama. Važno je na-

\footnotetext{
${ }^{9}$ KUD „Matija Gubec“ osnovan je 1968. godine, a prije njega na području Slavonskog Kobaša djelovao je tamburaški zbor "Gombović" i društvo „Smilje“ do 1941. godine (Jagodar i Berbić Kolar 2020: 195-196).
}

${ }^{10} \mathrm{Ne}$ zna se gdje se čuvaju pjesme koje je zapisivala Janja Krištofić (op. a.). 
glasiti da se kolo „polako“ pleše bez instrumentalne pratnje. Razlog tomu je što su se kola „polako“ i „nabrzo" plesala i ljeti i zimi. Zimi su bile niske temperature pa svirači nisu svirali (nego su stajali prekriženih ruku preko tambura (op. a). ${ }^{11}$ Kolo „polako“ pleše se u „zatvorenom kružnom kolu u kojem su plesači zbijeni i čvrsto vezani rukama prekriženim preko prednje strane susjednoga plesača s drugim od sebe na lijevu i desnu stranu“ (Ferić 2016: 118). Kob aško kolo „polako“ pleše se, kao i većina slavonskih šetanih kola, šetajućim korakom s desna na lijevo - dva koraka prema unutra pa dva koraka nazad, i pjeva se u dva zbora - najčešće ženske pjevaju prve, potom muškarci u drugom tonalitetu ponavljaju stihove. Ferić (2016: 117) navodi da ples obično započinje „laganim šetanim korakom i kratkim napjevima u sporijem tempu u izvedbi jedne skupine i ponavljanjem napjeva i stihova u drugoj skupini. ${ }^{12}$ Ako su pjesme koje se pjevaju u kolu „polako“ epske, onda su stihovi bili duži, a ako su lirske, onda su tekstovi bili kraći. ${ }^{13}$ Kobaško kolo „polako“ Ferić (2016: 120) naziva i „kolo na polagano“ jer je kolo specifično po tome što ima „orijentalni tonski niz od pet tonova“. ${ }^{14} \mathrm{U}$ nastavku navodimo pet tekstova pjesama koje se najčešće pjevaju u kolu „polako“.

\section{U noj čarnoj gori \\ Pjevano kolo "polako"}
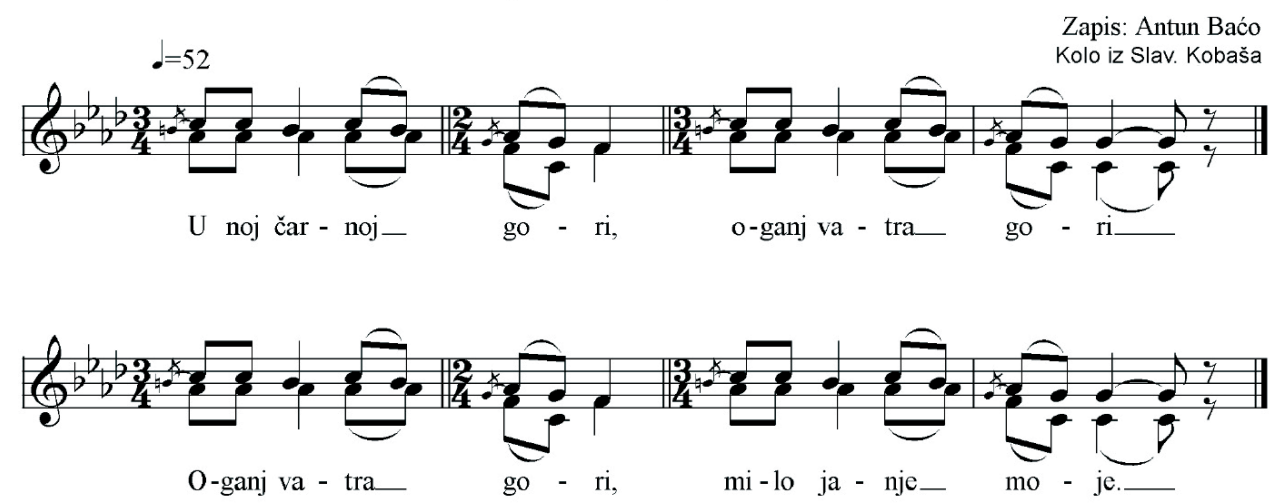

Slika 1. Notni zapis šetanog kola „polako“ (izvor: Ferić 2016: 120)

${ }^{11}$ Iz razgovora s Mihaelom Ferićem, Slavonski Kobaš - Slavonski Brod. 30. 3. 2020.

${ }^{12}$ Ferić (2016: 118) izvodi pravilo za pjevanje u šetanim kolima: „Gotovo u pravilu s dvjema skupinama pjevača predvođene solo pjevačicom ili pjevačem te ponavljanjem napjeva i pjesme (stihova) u drugom zboru. Druga je kombinacija da vodeća pjevačica ili pjevač otpjevaju napjev bez pratećih glasova, a ponove svi u dvoglasu."

${ }^{13}$ Iz razgovora s Mihaelom Ferićem.

${ }^{14}$ U pojedinim pjesmama kola „polako“ napjev se izvodi u dvije skupine „tako da se u drugoj skupini ponovi isti napjev na drugi stih, uz dodatak milo janje moje“ (Ferić 2016: 120). 


\section{U ‘noj čarnoj gori}

U 'noj čarnoj gori, oganj vatra gori.

Oganj vatra gori, milo janje moje.

Uz tu vatru dušo, trideset junaka.

Trideset junaka, milo janje moje.

Svi zdravi, veseli, sam' jedan ranjeni.

Sam jedan ranjeni, milo janje moje.

Al' govori, dušo, taj jedan ranjeni.

Taj jedan ranjeni, milo janje moje:

„Nemojte me braćo ostaviti sama,

ostaviti sama, milo janje moje.

Kopajte mi raku kod svetog Ivana, kod svetog Ivana, milo janje moje.

Na koplje duboko, na sablju široko,

na sablju široko, milo janje moje

Moju desnu ruku na van izvadite,

na van izvadite, milo janje moje.

Mog' vranog konjica za nju privežite,

za nju privežite, milo janje moje.

Nek' me konjac žali kad me draga neće,

kad me draga neće, milo janje moje.

Draga bi plakala kad bi za to znala,

kad bi za to znala, milo janje moje.

Pismo bi' joj piso, čitat mi ga ne zna,

čitat mi ga ne zna, milo janje moje.

Poruk' bi joj slao, svaj bi svitak znao,

svaj bi svitak znao, milo janje moje.“ (Ferić 1996: 164)

Pjesma $U$ 'noj čarnoj gori pjeva o neimenovanom ranjenom junaku iz Kobaša koji se borio protiv Turaka ${ }^{15} \mathrm{i}$ koji svojim suborcima govori da ga pokopaju kod

15 Turci su 1526. godine započeli s napadima na Kobaš, a osvojili su ga u studenom 1530. godine (usp. Jagodar 2019: 60; Milčić i Regan 2014: 165). Kobaš je oslobođen od Turaka 1688. godine, a potpuno 1691. godine (Marković 1994: 102-103). 
crkve svetog Ivana. ${ }^{16}$ Ovaj tekst opisuje kako su Kobašani sudjelovali u ratovima protiv Turaka. Skenderović (2019: 159) Slavonski Kobaš svrstava u jedno od triju mjesta koja su bila „vrata Bosne“ (uz Slavonski Brod i Dubočac), a i Slavonski Kobaš bio je „bremenit poviješću ratova“. Zamjetljiva su ponavljanja uobičajenih motiva iz usmene književnosti ovih prostora: milo janje moje. Motiv janjeta također je čest motiv koji ima biblijski predznak i značenje te se kulturološki jasno uvrštava u prostor posavskoga sela Slavonski Kobaš i vremena nastanka ovih napjeva za šetana kola. Botica posebno ističe biblijske motive u usmenoj književnosti za koje kaže: „ Iz cjeline hrvatske tradicijske kulture, i posebice usmene književnosti u njoj, naziru se dvije temeljne teme: autohtoni narodni život i običaji proizišli iz naravi hrvatskoga nacionalnog bića i biblijski poticaji jer je odmah po pokrštenju Hrvata, od sedmoga stoljeća pa nadalje, Biblija snažno prožela sve vidove hrvatskoga života." (Botica 2004: 18)

Tekstovi sljedećih dviju pjesama vezani su uz rijeku Savu:

\section{Lipa ti je Sava voda 'ladna}

Lipa ti je Sava voda 'ladna

Kuda teče nije zemlja gladna

Još su lipši bijeli gradovi

Krajem Save kano labudovi. (Kačić Miošić u: Vončina 1988: 632-634)

Tekst Lipa ti je Sava voda 'ladna pjeva o rijeci Savi oko koje se i formiralo selo Slavonski Kobaš, ali i mnoga druga sela Posavlja, stoga je razumljivo da su Kobašani opjevali i rijeku Savu u svojim kolima. ${ }^{17} \mathrm{U}$ pjesmi se navodi kako je zemlja uz rijeku Savu plodna te da su zbog toga mnogi gradovi i sela napravljeni uz riječni tok. Motiv rijeke Save čest je u usmenoj tradiciji Posavljaka s obje

${ }^{16}$ Može se pretpostaviti da je junak htio da ga pokopaju kod crkve svetog Ivana Krstitelja u Slavonskom Kobašu koja je sagrađena 1781. godine (Dukić 2002: 76). Ipak, ta je tvrdnja upitna jer je kobaško groblje bilo na Kloštru kod Slavonskog Kobaša, a ondje su se ukapali i župljani iz Kuta, Bebrine i Banovaca (Zirdum 2001: 34, 42).

${ }^{17}$ Osim u kolima, Kobašani su opjevali rijeku Savu i u bećarcima: Kobaš selo leži pokraj Save / i na ušću pritoke Orljave; Kobaš selo pokraj rijeke Save / u njemu su curice garave; Kobaš ovdi, a Kobaš i priko, / dojdi vamo preko Save diko; Oj Kobašu pokraj rijeke Save, / najlipše sam tu provela dane; Alaj sam se nauživo lipa / pokraj Save i zelena sipa; Ej, Sava valja drvlje i kamenje, / a Orljava momke neženjene; Vozila se Šokica po Savi / suknjom vesla keceljom kormilari; Nema više preko Save mosta, / sam sjećanje na njega nam osta; Sad šetamo po savskom nasipu / i gledamo Motajicu divnu; Živili smo kao selo jedno / preko Save most nas povezivo; Pružio se priko Save lanac / oj Slavonko voli te Bosanac; Kobaš ovdi a Kobaš i priko / dojdi vamo preko Save diko; Sve ću svoje prodati na Savi / za curine okice u glavi; Udade se i poveza glavu / bolje da je skočila u Savu (Berbić Kolar i Jagodar 2020). 
strane rijeke Save jer je Sava značila život u svakom smislu te riječi. Skenderović (2019: 147) navodi: „Život ljudi u Brodskom Posavlju obilježen je odnosom prema rijeci Savi. Sezonski ritam poplava stoljećima je na širem prostoru utjecao na osnivanje naselja i njihovo prometno povezivanje, a kod naselja uz samu rijeku i na tip kuća koje su građene."

\section{Savo vodo, lipoga imena}

Ej, ${ }^{18}$ Savo vodo lipoga imena,

donesi mi šta si mi odnila.

Odnila sam bratca i dragoga

Što $b$ > divojko za kojeg dala?

Za bratca bi čarne oči dala,

a za dragog đerdan ${ }^{19}$ ispod vrata.

Koliko bi za kojeg žalila?

Bratca žalim dok sam godi živa,

a dragoga od stola do peći.

Svuda prošla, al' bratca ne našla.

Selom prođoh pa dragoga nađoh! ${ }^{20}$ (Ferić 1996: 166)

Pjesma Savo vodo, lipoga imena pjeva o djevojačkoj tuzi za bratom i momkom koji su stradali u rijeci Savi. Brata djevojka više žali jer više braće ne može imati, a momka će moći naći u selu. Tipični su to motivi za usmeno stvaralaštvo, odnos sestre prema bratu je mnogo intenzivniji, negoli odnos djevojke prema mladiću. Iz toga se itekako može iščitati tradicionalan odnos prema obitelji kao temeljnom stupu društva kod Šokaca.

\section{Oj Kobašu, moje selo ravno}

Oj Kobašu, moje selo ravno

od davnina ti si bilo slavno.

I u tebi široki sokaci,

po njima su šetali junaci (Valentina Džinić, 2019)

\footnotetext{
${ }^{18}$ Usklik Ej ponavlja se prije svakog stiha.

${ }^{19}$ Počimalja KUD-a „Matija Gubec“Valentina Džinić navodi da se danas pjeva dukat, umjesto đerdan.
} 
Oj Kobašu, moje selo ravno pjesma je koja pjeva o Kobašu, poznatom posavskom selu kojim su u prošlosti šetali poznati junaci koji su se borili protiv Turaka te u ratovima tijekom Prvog i Drugog svjetskog rata. ${ }^{21}$

\section{Dvi su druge virno virovale}

Dvi su druge virno virovale, drugijuć' su jetrve postale, za dva brata i u jedne dvore. Jedna mila svekru i svekrvi, jedna mila, a druga nemila.

Nemila je miloj govorila:

„Svekrvice po bogu sestrice, koje s' bilje u dvore donila, pa si svekru i svekrvi mila?“ „Ja sam troje bilje donila.

Prvo bilje rano uraniti, drugo bilje ne odgovoriti, treće bilje svagdi priskočiti, dvor pomesti i vode donesti. tako ćeš im mlada ugoditi.“ (Ferić 1996: 166-167)

Riječi pjesme govore o prijateljstvu dviju djevojaka koje su se udale za dva brata. Jedna je djevojka bila vrjednija pa su je muževljevi otac i majka zavoljeli, a drugu nisu voljeli pa je zamolila prijateljicu da ju savjetuje kako da im se umili. Prijateljica joj je savjetovala da se ranije ustaje, da im ne odgovara kad joj nešto govore i da im uvijek bude na raspolaganju pa će ju zavoljeti. Ta je pjesma zanimljiva jer se njome savjetuju djevojke koje su bile udane i koje su se planirale udavati kako da se ponašaju prema novoj obitelji u koju dođu da budu što bolje prihvaćene. O odnosu drúga i njihovome prijateljevanju govori i Janković: „Drugarstvo među djevojkama je važnije i čvršće, nego među momcima. Osobito je važno za ljubav. Lovretić opširno opisuje to drugarstvo. Drúga

\footnotetext{
${ }^{21}$ Najpoznatiji kobaški junaci i junakinje koji su se borili protiv Turaka su Mara Margetić, Ivan Sekula, Marijan Terzić i barjaktar Margetić (Dukić 2002: 32; Ilić Oriovčanin 1874: 78, 86-87, 92-97; Jagodar 2019: 64-69; Krpan 1994: 10; Rem 1965: 26). O Kobašu i Kobašanima u Prvom svjetskom ratu pisali su Blaževac Pajkov (2015: 138-141) te Jagodar i Berbić Kolar (2020: 143-152), a u Drugom svjetskom ratu Jagodar (2012: 42-45) te Jagodar i Berbić Kolar (2020: 200-220).
} 
drúgi pomaže kod sklapanja poznanstava, poručivanja, pozdravljanja, i ostalih ljubavnih zgoda" (Janković 1970: 114). Ona svakako ima i edukativni karakter opet gledano kulturološki u odnosu prema svekru kao glavi slavonske kuće i svekrvi kao gazdarici, a mogli bismo reći, današnjim rječnikom i upraviteljici velikih obitelji koje su živjele zajedno u jednom domaćinstvu.

\section{Kola „na brzo“}

Kolo „nabrzo“ dinamičnije je od kola „polako“ jer se u ples unosi „drmanje, plesanje uz intenzivne vertikalne titraje “22 (Ivančan 1964: 24). Prva dva stiha otpjevaju se uz titraje potom dolazi do poskoka desnom nogom i onda započinje brzo kruženje uz pjevanje do kraja pjesme. Mihael Ferić navodi da šetano kolo „nabrzo“ koje se pleše u Slavonskom Kobašu nije puno brže od kola „polako“, ali se razlikuje po tome što plesači rade duple korake u plesanju, tj. plešu ga kasajućim koracima. Nakon što otpjevaju dva stiha, plesači poskoče i počnu plesati ubrzanim korakom i kretanjem prema plesačima nasuprot (usp. Ferić 2016: 118). Treba svakako spomenuti i specifično pjevanje tog kola. Ferić (2016: 122) spominje da kobaško kolo „na brzo“ ima četiri takta i da se najčešće izvodi u dvjema skupinama pjevača: muškoj i ženskoj pa se svaki stih ponavlja u dva zbora. Ono što treba istaknuti, a što i Ferić (2016: 124) smatra važnim, jest da sadržaj pjesme mora biti „jasan i glasan“, stoga kolo „na brzo“ (ali i kolo „polako“) ne smiju biti izvođeni uz instrumentalnu pratnju jer instrumentalna pratnja „pokriva pjevani tekst“, a za ta je dva šetana kola tekst pjesme važniji od samog plesa jer se njime prenosi identitet i kulturološka odrednice Kobaša i cijele Slavonije.

\section{Ajde kolo da skoknemo}

Pjevano kolo "na brzo"

Slav. Kobaš Zapis: Mihael Ferić

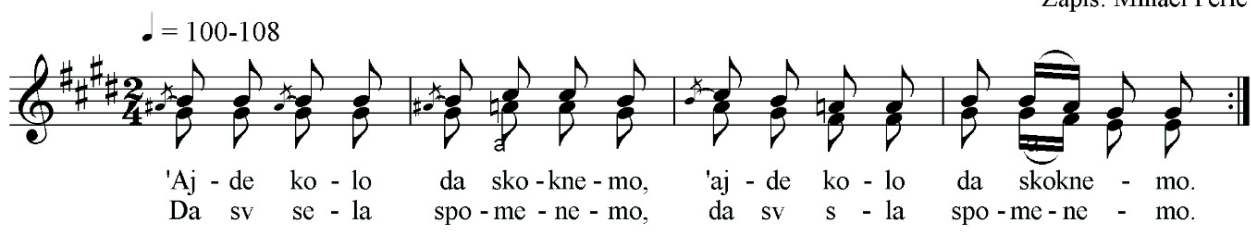

Slika 2. Notni zapis šetanog kola „na brzo“ (izvor: Ferić 2016: 122)

${ }^{22}$ Ivančan drmanje vezuje uz najpoznatije šokačko kolo - drmeš, ali se drmeš razlikuje od kola „na brzo“. 


\section{'Ajde kolo da skoknemo}

'Ajde kolo da skoknemo,

da sva sela spomenemo.

'Ajde kolo malo, malo,

Oriovac ogledalo,

a Malino, selo malo,

u dvi riči sve je stalo.

A Lužani teke, teke

u Kobašu lipe seke.

Kapela je mala varoš,

Bili Brižak ružmarinak,

Vrbova je janje moje,

a Štivica fijolica.

Komarnica selo lipo,

Magić Mala progovara:

da u Siče sve utiče,

a Živike šige mige,

s njima Priča ima brige.

Kobaškinje cure bose,

nacoklaju svoje kose,

svakom živom poprkose. (Ferić 1996: 168-169)

Pjesma 'Ajde kolo da skoknemo pjeva o selima blizu Slavonskog Kobaša i s kojima su se Kobašani na neki način povezali. Opjevana su sela Oriovac (današnje općinsko središte općine Oriovac kojoj pripada i Slavonski Kobaš), Malino, Lužani, Kobaš, Kapela (Nova Kapela), Bili Brižak (Bili Brig), Vrbova, Štivica, Komarnica, Magić Mala, Siče, Živike i Pričac, a na kraju su spomenute Kobašakinje (Kobašanke) koje svojom specifičnom, tradicionalnom frizurom, privlače momke. Ferić (2016: 122) spominje da slična pjesma postoji i u selu Vrbova u kojoj se hvale i izruguju susjedna sela i mještani tako da ova kobaška pjesma nije jedina koja opjevava susjedna i bliža mjesta.

Ajde kolo da skočimo

Ajde kolo da skočimo, da vidimo 'ko li more, 
'ko li more 'ko ne more.

A ja mogu fala Bogu,

a ja znadem 'ko ne more.

Ko se j' skoro oženio

svega dobra poželio.

I ljubice i ružice

i za glave divojačke,

divojačke i momačke. (Jagodar i Berbić Kolar 2020: 355)

Pjesma Ajde kolo da skočimo pjeva o samim pjevačima i njihovim mogućnostima plesanja kola „na brzo“. Plesači trebaju biti uvježbani kako im drugi plesači ne bi stajali po nogama ili odjeći i na taj način nekoga ozlijedili. Spretniji plesači uvijek su ubrzavali korak kako bi pojedini plesači izašli iz kola ako nisu bili fizički spremni za brži tempo. Budući da je kolo imalo posebno značenje u seoskoj sredini jer su se u kolu okupljali i mladi i stari i djeca, često je poslužilo i za sastajanje i ljubav (Janković 1970: 60).

\section{Oj, divojko dušo moja}

Oj, divojko dušo moja!

Ne da mi se mat' udati.

Ja se ne bi ni udala,

a sad mi se dragi ženi.

Kućani ga natiruju,

natiruju, ne viruju,

a ja mlada Boga molim

da g' narede na rabotu.

Trefila se baš rabota,

baš rabota do Božića,

od Božića do prolića.

On ostade do jeseni

i dopade mladoj meni. (Jagodar i Berbić Kolar 2020: 373)

Oj, divojko dušo moja govori o udaji djevojke kojoj majka brani da se uda za voljenog muškarca koji se zbog toga ženi za drugu djevojku jer ga njegovi 
tjeraju da se oženi. Djevojka moli Boga da ga pošalju na „rabotu“23 kako se ne bi oženio za drugu. U Slavonskom Kobašu nije bila rijetkost da su roditelji branili djevojkama ili dečkima da se udaju ili ožene za nekog u koga su bili zaljubljeni. Zbog toga je dio djevojaka ostao neudan, a dio momaka neoženjen. Ipak, većina se udala ili oženila za osobe u koje su bili zaljubljeni i s njima zasnivali obitelji. ${ }^{24}$ O tome piše i Janković: „Djevojčinim je roditeljima moralo biti stalo do toga, da se njihovo dijete uda u dobru i bogatu kuću, gdje će djevojka manje raditi, a po mogućnosti bolje živjeti“ (Janković 1970: 155).

\section{Šipak drvo urodilo}

$\mathrm{Oj}$, na našem igralištu, na našemu sastalištu,

šipak drvo urodilo,

đerzi su ga salomili,

na njega kape vješajući,

a djevojke gledajući.

Djevojke su vragometne,

obrve su nagarile,

dok su momke primamile.

Solufe su nakuštrale,

dok su momke izmuštrale.

I još svoje kose glade,

iz momaka srce vade. ${ }^{25}$ (Valentina Džinić 2019.)

Pjesma Šipak drvo urodilo pjeva o šipku (R. canina) koji je rastao na igralištu. Kako do Drugog svjetskog rata na području Slavonskog Kobaša nije bilo igrališta, zaključuje se da je ova pjesma nastala pedesetih godina 20. stoljeća. ${ }^{26}$ Budući da je šipak na igralištu dobro urodio, nagnule su mu se grane prema zemlji od težine plodova, a momci su na njega stavljali kape pa su grane pod težinom pukle i šipak je polomljen. Momci su na igralište dolazili igrati nogomet, stoga su

\footnotetext{
${ }^{23}$ Rabota je rad koji su ljudi morali odraditi za potrebe općine ili države i za taj rad nisu bili plaćeni. O raboti u Političkoj općini Kobaš pisali smo u Jagodar i Berbić Kolar (2020: 63-67).

${ }^{24}$ Iz razgovora s Katom Sekulić, ali i usmene predaje drugih mještana Slavonskog Kobaša (op. a.)

${ }^{25}$ Ferić (1996: 168) zapisuje drugačije stihove od 7. do 10. stiha: „solufe su napudrale / dok su momke izmuštrale / Obrve su navranile / dok su momke privabile."

${ }^{26}$ Zemljište za prvo nogometno igralište odobrio je Mjesni narodni odbor Slavonski Kobaš 14. siječnja 1950. godine jer je 5. siječnja iste godine DVD Slavonski Kobaš osnovao nogometnu sekciju (Jagodar 2012: 52).
} 
morali skinuti svoje kape kako bi se manje znojili. Djevojke su ih dolazile gledati kako bi procijenile koji im se više sviđa. Često su bile našminkane i zavodile su muškarce dok su gladile kosu, a momci im nisu mogli odoljeti pa su nakon utakmice odlazili šetati uz Savu ili predvečer dolazili na igralište i ondje se družili.

\section{U Kobašu kolo igra}

U Kobašu kolo igra.

U tom kolu sve divojke,

sve divojke jednolike

samo Mara blidolika

u pojasu tankovita. (Valentina Džinić 2019)

Jedna od najpoznatijih pjesama u kolu „na brzo“ je pjesma U Kobašu kolo igra koja pjeva o djevojačkom kolu u kojemu su sve djevojke bile rumene, jedino je djevojka Mara $^{27}$ bila bljedolika i mršava. Mara je često ime koje se koristi u pjesmama koje se pjevaju u Slavonskom Kobašu jer je dosta djevojaka imalo to ime pa se nije znalo kojoj je djevojci upućena pjesma.

\section{Divojčice ljubičice}

Divojčice ljubičice, moja draga ružičice.

Cvati, cvati kano ruža, dok ne stekneš jednom muža.

Povenut' će tebi ruža., jer je ruža vremenita, a žena je vjekovita. Ajd' u kolo divojčice, divojčice ružičice.

Dok si mlada, dok si lijepa, svakome si mušku draga.

Kad ostariš, kad oslabiš, ni’ko tebe gledat neće. (Ferić 1996: 170)

${ }^{27}$ Luka Ilić Oriovčanin u knjizi „Narodni slavonski običaji“ pjeva o djevojci Mari Terzić u koju se zaljubio Devin aga iz Bosanskog Kobaša (1846: 37-40). Pjesmu je zapisao u prvoj polovici 19. st. pa se može zaključiti da je djevojka Mara više puta opjevana u kobaškim pjesmama. 
Pjesma Divojčice ljubičice jedna je u nizu pjesama kojima se savjetuje djevojkama da se trebaju zaljubiti i udati. Motiv ljubičice čest je u usmenoj književnosti i obično se povezuje uz djevojke i djevojčice. Riječi pjesme sugeriraju djevojkama da trebaju uživati u mladenačkim danima dok se ne zaljube i ne udaju. Ljepota je djevojaka prolazna i trebale bi ju iskoristiti dok su mlade, stoga ih se poziva u djevojačko kolo kako bi ih momci vidjeli i kako bi lakše pronašle svog budućeg muža jer ih nakon mladosti nitko neće gledati. Takve pjesme nisu rijetkost jer su se djevojke rano udavale, stoga su ih roditelji i okolina na neki način prisiljavali na udaju da ne ostanu „stare“ djevojke i da se ne udaju.

\section{Za gradom Carigradom}

Oj, divojko dušo moja!

$\mathrm{Oj}$, za gradom Carigradom,

carski konji pokradeni, nadaleko odvedeni, čak Novaku Debeljaku.

Car Novak poručuje:

„Pošalj’ meni vrane konje, vrane konje Omerove i Alata i Dorata i onoga dobrog konja, koj' ne jede sitna sina, i ne zoblje bile zobi, već on gleda u Dunavo.“ (Ferić 1996: 168)

U korpusu pjesama koje se pjevaju, zabilježena je i pjesma koja pjeva o plemenitim životinjama bez kojih su transport i putovanje bili nezamislivi do sredine 20. stoljeća. Za gradom Carigradom pjesma je koja pjeva o ukradenim konjima. U Carigradu su ukradeni Omer-pašini konji Alat i Dorat te još jedan neimenovani konj pa su se mnogi uključili u potragu za konjima. Budući da je Kobaš više od 150 godina bio pod turskom upravom i da je od kraja 17. stoljeća bio dio Vojne krajine i graničio s Osmanlijskim Carstvom, razumljivo je da se u kobaškim šetanim kolima pojave stihovi iz prošlih vremena, vezanih uz Turke i orijentalnu kulturu. 


\section{Zaključak}

Šetana su kola dio kulturne tradicije brodskoga Posavlja. U radu su uzeta za primjer šetana kola iz Slavonskoga Kobaša kao posavskoga mjesta u kojemu se čuva i njeguje tradicija i kultura posavskoga kraja. U selu je vrlo aktivno kulturno-umjetničko društvo, ali su i svi ostali seljani jako veliki zaljubljenici u šokačku kulturu, šokački izričaj, šokački divan i običaje te je sva usmena tradicijska kultura iznimno živa i bogata i u svakodnevnoj komunikaciji, i životu. Šetana su kola spoj nekoliko kulturoloških elemenata glazbe, plesa, usmene književnosti i usmenog izričaja na mjesnom govoru (kobaškom govoru koji pripada posavskom poddijalektu slavonskoga dijalekta). U njima se ogleda bogatstvo šokačke kulture i šokačkih tradicijskih vrijednosti. Tekstovi šetanih kola služili su najčešće za zabavu i rasterećenje. U šetanim se kolima poučavalo o svim elementima svakodnevnoga života, od povijest (ratovi protiv Turaka, Prvi svjetski rat, Drugi svjetski rat), geografije (bliža i dalja sela koja su okruživala selo Slavonski Kobaš, ali i prekosavski krajevi Bosne i Hercegovine), higijene, domaćinstva (kako biti dobra mlada), usmene predaje pa sve do nekih humorističnih situacija kojima je svrha bila rasteretiti i nasmijati. Veliki zaljubljenik u posavsku tradicijsku kulturu je profesor Mihael Ferić koji je dobrim dijelom i zaslužan što postoji zapisani korpus šetanih kola koja su nam poslužila kao temelj u analizi i interpretaciji. Ovim radom istraživanje šetanih kola brodskoga Posavlja tek je započeto. Vjerujemo da će se ovom temom pozabaviti i stručnjaci iz drugih znanstvenih i umjetničkih područja te da će šetana kola dobiti svoje zasluženo mjesto na našoj kulturnoj i tradicijskoj, znanstvenoj i stručnoj mapi, ali jednako tako i da će biti uključeni u kurikule nastavnih predmeta. Kao prijedlog budućim istraživanjima uočili smo mogućnost obrade tekstova koji se izvode uz šetana kola, a koja mogu poslužiti i kao lingvistički predlošci za proučavanje slavonskoga dijalekta, ali i za književnu analizu usmene tradicije, usmene književnosti, kraja u kojemu su nastala te u tome smislu mogu biti dijelom nastavnih kurikula integrirane nastave povijesti, hrvatskoga jezika, glazbene umjetnosti, sociologije.

\section{Literatura}

Berbić Kolar, Emina; Jagodar, Josip. Bećarci Slavonskoga Kobaša u kontekstu nematerijalne kulturne baštine Brodskoga Posavlja. Vinkovci: Šokačka rič 17 (rad u tisku).

Blaževac Pajkov, Mate. 2015. Neoplakani slavonski soldati (1914. - 1918.). Donja Bebrina: Udruga povjesničara i baštinika zavičajne starine Slavonije, Baranje i Srijema. 
Bošković-Stulli, Maja. 1971. Usmena književnost u sklopu povijesti hrvatske književnosti. U: Usmena književnosti - izbor studija i ogleda. Maja Bošković-Stulli, prir. Zagreb: Školska knjiga, 31-58.

Bošković-Stulli, Maja. 1978. Usmena književnost. U: Povijest hrvatske književnosti. knjiga I. Zagreb: Liber-Mladost. 7-325.

Bošković-Stulli, Maja. 2005. Od bugarštice do svakidašnjice. Zagreb: Konzor.

Botica, Stipe. 1995. Hrvatska usmenoknjiževna čitanka. 1. izdanje. Zagreb: Školska knjiga.

Botica, Stipe. 2004. Biblijske teme u hrvatskoj usmenoj književnosti. Osijek: Zlatni danci 5.

Delić, Simona. 2001. Između kletve i kletve: Tema obitelji u hrvatskoj usmenoj baladi. Zagreb: Hrvatska sveučilišna naklada.

Dukić, Mijo. 2002. Kloštar u Kobašu. Zagreb: Hrvatsko književno društvo svetog Jeronima.

Ferić, Mihael. 2016. Folklorna glazba panonske plesne zone. Vinkovci: Kulturni centar „Gatalinka“.

Ferić, Mihael. 1996. Pjesme moje u knjigama stoje: Hrvatske pučke pjesme, plesovi i poskočice brodskog Posavlja. Slavonski Brod: Folklorni ansambl Broda: Matica hrvatska.

Hadžihusejnović-Valašek, Miroslava. 2002. Slavonska folklorna glazba 18. stoljeća prema pisanim izvorima. U: Osječki zbornik. XXVI/ 20, 201-214.

Ilić, Helena. 2018. Nematerijalna baština i tradicija - sastavnice hrvatskog kulturnog identiteta. Pula: Diplomski rad.

Ilić Oriovčanin, Luka. 1846. Narodni slavonski običaji. Zagreb: Tisak Franje Suppana.

Ilić Oriovčanin, Luka. 1874. Lovorike gradiškoga narodnoga graničarskoga puka br. 8. Zagreb: Tisak Dragutina Albrechta.

Ivančan, Ivan. 1964. Geografska podjela narodnih plesova u Jugoslaviji. U: Narodna umjetnost - hrvatski časopis za etnologiju i folkloristiku III/ 1, 17-38.

Ivančan, Ivan. 1963. Prilozi istraživanju socijalne uloge plesa u Hrvatskoj. U: Narodna umjetnost - hrvatski časopis za etnologiju i folkloristiku II/ 1, 97-105.

Jagodar, Josip. 2012. Povijest Dobrovoljnog vatrogasnog društva Slavonski Kobaš. Slavonski Kobaš: Vlastita naklada.

Jagodar, Josip. 2019. Toponim Kobaš i slavni kobaški junaci u djelima Lovorike gradiškoga narodnoga graničarskoga puka br. 8 i Narodni slavonski običaji Luke Ilića Oriovčanina.U: Luka Ilić Oriovčaninu, zbornik radova znanstveno-stručnog skupa. Slavonski Brod - Oriovac: Hrvatski institut za povijest - Podružnica za povijest Slavonije, Srijema i Baranje i Općina Oriovac, 59-74.

Jagodar, Josip i Berbić Kolar, Emina. 2020. Kultura pamćenja Slavonskoga Kobaša u povijesno-jezičnom kontekstu. Osijek: Fakultet za odgojne i obrazovne znanosti Sveučilišta Josipa Jurja Strossmayera u Osijeku.

Jakobson, Roman; Bogatirjov, Pjotr. 1971. Folklor kao naročit oblik stvaralaštva. U: Usmena književnosti - izbor studija i ogleda. Maja Bošković-Stulli, prir. Zagreb: Školska knjiga, 17-30.

Janković, Slavko. 1970. Šokačke pismice II, Vinkovci: Matica hrvatska. 
Kekez, Josip. 1988. Usmeno stvaralaštvo u suvremenoj hrvatskoj poeziji. U: Suvremeno hrvatsko pjesništvo. Ante Stamać, ur. Zagreb: Zavod za znanost o književnosti, 197-249.

Kekez, Josip; Pandžić, Vlado. prir. 1996. Hrvatske usmene pjesme i brojilice. Zagreb: Alfa.

Krpan, Stjepan. 1994. Zavičajnici - Portreti malo spominjanih, prešućivanih i zaboravljenih. Slavonski Brod: Matica hrvatska, Ogranak Slavonski Brod.

Leček, Suzana. 2005. Seljačka sloga u Slavoniji, Srijemu i Baranji. Slavonski Brod: Hrvatski institut za povijest - Podružnica za povijest Slavonije, Srijema i Baranje.

Marković, Mirko. 1994. Brod: Kulturno-povijesna monografija. Slavonski Brod: Matica hrvatska Ogranak Slavonski Brod.

Milčić, Nenad i Regan, Krešimir. 2014. Srednjovjekovne utvrde požeške gore i njezina nizinskog posavskog sliva. U: Radovi Zavoda za znanstveni i umjetnički rad u Požegi. br. 3, 141-185.

Orlić, Ivona. 2013. Istra kroz tri generacije: između svakodnevne konstrukcije identiteta i turističkog proizvoda. Pazin: Etnografski muzej Istre.

Palameta, Miroslav. 2018. Reljefni prikazi kola na stećcima. U: Hercegovina - Časopis za kulturno i povijesno naslijeđe. br. 4, 87-116.

Rem, Vladimir. 1965. Tragom prošlosti Broda. Slavonski Brod: Kulturno-prosvjetne zajednice Slavonskog i Bosanskog Broda.

Skenderović, Robert. 2019. Kobaš, Dubočac i Brod na Savi - povijest razvoja trojih susjednih »vrata Bosne«. U: Historiae patriaeque cultor - Zbornik u čast Mate Artukovića u prigodi njegova 65. rođendana, Suzana Leček, ur. Slavonski Brod: Hrvatski institut za povijest - Podružnica za povijest Slavonije, Srijema i Baranje, 147-162.

Solar, Milivoj. 1994. Teorija književnosti. Zagreb: Školska knjiga.

Toldi, Zvonimir. 1985. Stihom od Berave do Orljave. Slavonski Brod: Muzej Brodskog Posavlja.

Toldi, Zvonimir. 1994. Nek se spominja i pamti život i običaji seljačkog svita u Brockom Posavlju. knjiga 2. Slavonski Brod: Folklorni ansambl Broda.

Vitez, Zorica; Marks, Ljiljana; Lozica, Ivan; Muraj, Aleksandra; Zebec, Tvrtko; Matošević, Grozdana. 2016. Hrvatski običaji i druge tradicije. Zagreb: Mozaik knjiga

Vončina, Josip. 1988. Kačić $i$ Reljković na razmeđi epoha. Zagreb: Sveučilišna naklada Liber. Zirdum, Andrija. 2001. Počeci naselja i stanovništvo brodskog i gradiškog kraja 1698. - 1991. Slavonski Brod: Hrvatski institut za povijest - Podružnica za povijest Slavonije, Srijema i Baranje.

\section{Razgovori}

1. Valentina Džinić (1991.). Slavonski Kobaš. razgovor obavljen 6. 12. 2019. - Valentina Džinić je rođena Kobašanka, počimalja u KUD-u „Matija Gubec“. Diplomirala je religioznu pedagogiju i katehetiku 2017. godine na Katoličkom i bogoslovnom fakultetu u Zagrebu. Trenutačno živi u Slavonskom Kobašu i nije udana. 
2. Kata Sekulić (1946.). Slavonski Kobaš - Štivica, telefonski razgovor obavljen 28. 3. 2020. - Kata Sekulić rođena je i cijeli život provela je u Slavonskom Kobašu. Završila je šest razreda osnovne škole. Godine 2019. napisala je „Katinu pismaricu iz Slavonskog Kobaša" na kobaškoj ikavici. Od 2020. živi u Štivici u Domu za starije osobe.

3. Mihael Ferić (1939.). Slavonski Kobaš - Slavonski Brod, telefonski razgovor obavljen 30. 3. 2020. -Mihael Ferić rođen je u Slavonskom Kobašu gdje je i živio i radio nekoliko godina. Posljednjih desetljeća živi i radi u Slavonskom Brodu, ali redovito posjećuje Slavonski Kobaš gdje ima rodbinu. Napisao je nekoliko knjiga u kojima je zapisao pjesme iz Slavonskog Kobaša. 


\section{KOBAŠ WALKED CIRCLE-DANCE - CONTRIBUTIONS TO THE STUDY OF THE SLAVONIAN INTANGIBLE CULTURAL HERITAGE}

Abstract
Emina BERBIĆ KOLAR
Faculty of Education
Josip Juraj Strossmayer University of Osijek
Ulica cara Adrijana 10
HR - 31 000 Osijek
eberbic@foozos.hr
Josip JAGODAR
Dr. Stjepan Ilijašević Primary School
Frankopanska 97
HR - 35 250 Oriovac
jjagodar91@gmail.com

The paper shows the cultural and identity significance of the walked circle-dance of the Posavina village of Slavonski Kobaš, namely: the "slowl" and the "quick" circle-dance as part of the intangible cultural heritage and tradition of the Croatian people. The šetana walked circle-dances, have been protected as intangible cultural property since 2009. Specifically, the Drežnica walked circle-dances are protected, and the subject of this paper are the Kobaš walked circle-dances, which belong to the same geographical and cultural circle as the Drežnica dances. The walked circle-dances are an important element of the cultural identity of the Šokac culture and identity. The aim of the paper is to contribute to the study of walked circle-dances, which are unjustifiably neglected in scientific and professional circles. The significance of walked circle-dances is extremely large in cultural, ethnological, linguistic and literary historical contexts and suggests the possibility of studying the layers of these dances as templates for interpreting history, oral literature, the language of the time in which they originated, ethnology, identity, and generally the cultural understanding of the peoples to whom they are bound as part of the cultural heritage and identity of one locality. The work is based on the methods of field material collection (texts of walked circle-dances), analysing and systemizing the collected material and working on the available archival material. Finally, recommendations are made for possible further research.

144 Keywords: walked circle-dances, Slavonski Kobaš, Posavina, oral literature, local speech 